\title{
PENGARUH MODEL PEMBELAJARAN TEAMS GAMES TOURNAMENT DAN NUMBERED HEADS TOGETHER TERHADAP HASIL BELAJAR TEKNIK LISTRIK DI SMK N 39 JAKARTA
}

\author{
Dewi Bilqis Mariska' ${ }^{1}$, Rusmono ${ }^{2}$, Moch.Sukardjo. ${ }^{3}$ \\ ${ }^{1}$ Mahasiswa Prodi Pendidikan Teknik Elektronika Fakultas Teknik Universitas Negeri Jakarta \\ ${ }^{2,3}$ Dosen Prodi Pendidikan Teknik Elektronika Fakultas Teknik Universitas Negeri Jakarta \\ E-mail: dewibilqism@gmail.com rusmono@unj.ac.id msukardjo@unj.ac.id
}

\begin{abstract}
Abstrak - Penelitian ini bertujuan untuk mengetahui apakah terdapat perbedaan hasil belajar teknik listrik antara peserta didik yang diajar dengan menggunakan model pembelajaran teams games tournament dan numbered heads together di SMK N 39 Jakarta.Jenis penelitian ini adalah penelitian eksperimen dengan rancangan penelitian menggunakan Pretest-Posttest Control Group Design.Populasi dalam penelitian ini adalahseluruh peserta didik di jurusan Teknik Audio Video. Pengambilan sampel menggunakan teknik simple random sampling.dan diperoleh peserta didik kelas X TAV 1 adalah kelas eksperimen yang diberikan perlakuan dengan model pembelajaran teams games tournament dan peserta didik kelas X TAV 2 adalah kelas kontrol yang diberikan perlakuan dengan model pembelajaran numbered heads together. Instrumen yang digunakan dalam penelitian ini adalah posttest untuk mengukur hasil belajar teknik listrik.Uji instrumen penelitian meliputi validasi ahli dan realibilitas instrumen.Analisis data terdiri dari uji normalitas menggunakan uji Lilliefors dan uji homogenitas menggunakan uji Fisher.Hasil perhitungan uji normalitas pada kelas yang menggunakan model pembelajaraan teams games tournament sebesar 1,154 dan kelas yang menggunakan model pembelajaran numbered heads together sebesar 1,116 dengan $\mathrm{L}_{\text {tabel }}$ 1,161 maka data berdistribusi normal. Uji homogenitas diperoleh hasil $\mathrm{F}_{\text {hitung }}$ 1,75 kurang dari $\mathrm{F}_{\text {tabel }}$ 1,87 maka data tersebut berdistribusi homogen.Perhitungan hipotesis statistik menggunakan uji-t dengan thitung 2,12 lebih besardari tabel 2,00, sehingga dapat disimpulkan bahwa terdapat terdapat pengaruh hasil belajar antara peserta didik yang menggunakan model pembelajaran Teams Games Tournament dan peserta didik yang menggunakan model pembelajaran Numbered Heads Together
\end{abstract}

Kata Kunci : model pembelajaran, Teams Games Tournament, Numbered Heads Together

Abstract - This research aims to determine the outcomes of differencesin electrical engineering learning among learners who were taught using learning model teams games tournament and numbered heads together in SMK N 39 Jakarta. This kind of research is experimental research with design using Pretest-Posttest Control Group Design. The population in this research are the students majoring in Audio Video Engineering. The sample is taken using simple random sampling technique and obtained that students class X TAV 1 are the experimental class which given treatment with learning model teams games tournament and students class X TAV 2 are the control class which given treatment with model numbered heads together learning. The instrument used in this research is posttest to measure the learning outcomes of electrical engineering. Research instrument test includes expert validation and instrument reliability. Data analysis consisted of normality test using Lilliefors test and homogeneity test using Fisher test.The calculations results of the normality test towards the classes that use the model of learning games tournament teams are 1.154 and classes that use model learning numbered heads together are 1.116 with $\mathrm{L}_{\text {tabel }} 1.161$ then the data is normally distributed. Homogeneity test obtained result $F_{\text {hitung }} 1.75$ less than $F_{\text {tabel }} 1.87$ then the data is homogeneous distributed.Calculation of statistical hypothesis using t-test with thitung 2,12 bigger than $t_{\text {tabel }} 2,00$, so it can be concluded that there is influence of learning outcomes between learners who used Teams Games Tournament learning model and learners that using the model of learning Numbered Heads Together

Keywords : learning model, Teams Games Tournament, Numbered Heads Together 


\section{PENDAHULUAN}

Sekolah Menengah Kejuruan (SMK) merupakan jenjang pendidikan menengah yang mempersiapkan peserta didik dengan membekalinya pengetahuan dan keterampilan agar dapat bekerja sesuai dengan bidang keahlian. SMK Negeri 39 Jakarta merupakan Sekolah Menegah Kejuruan (SMK) yang berada di Jakarta Pusat. Teknik Audio Video merupakan salah satu diantara tiga jurusan yang ada di sekolah ini. Teknik Audio Video membekali peserta didik agar terampil dalam bidang audio video, perakitan dan perbaikan televisi maupun perangkat audio. Teknik Listrik merupakan salah satu matapelajaran yang disampaikan pada kelas X jurusan Teknik Audio Video. Pada matapelajaran Teknik Listrik peserta didik diajarkan untuk memahami tentang teori kelistrikan.Teknik listrik merupakan salah satu matapelajaran produktif yang ada di dalam jurusan Teknik Audio Video.

Hasil pengamatan yang dilakukan peneliti di dalam kelas X TAV1 dan X TAV 2 bahwa dalam proses pembelajaran Teknik Listrik guru menerapkan strategi ekspositori. Dalam strategi ekspositori proses pembelajaran berpusat pada guru melalui ceramah, diskusi serta tanyajawab. Penerapan strategi ekspositori dirasa belum begitu mampu dalam meningkatkan motivasi belajar peserta didik. Hal tersebut dapat dilihat dari beberapa peserta didik yang belum memahami dengan jelas materi yang disampaikan oleh guru, karena saat guru menyampaikan materi terdapat peserta didik yang kurang konsentrasi dan mengobrol dengan peserta didik lain. Namun terdapat sebagian peserta didik yang lain dapat memahami materi yang disampaikan oleh guru secara langsung. Ketika guru memberikan kesempatan peserta didik untuk bertanya maka peserta didik hanya diam dan ketika diminta untuk menjawab pertanyaan, peserta didik menunjuk temannya untuk menjawab atau menjawab saat diminta oleh guru.

Kurang pahamnya peserta didik terhadap materi yang disampaikan akan berpengaruh terhadap hasil belajar peserta didik. Hasil belajar diperoleh setelah dilaksankannya ujian seperti ulangan harian, ujian tengah semester dan ujian akhir semester. Tercapainya hasil belajar yang baik apabila peserta didik dapat mencapai nilai KKM ( Kriteria Ketuntasan Minimal). KKM di SMKN 39 Jakarta pada tahunajaran 2016/2017 adalah 80. Jadi dari kriteria KKM tersebut, peserta didik dinyatakan telah berhasil apabila mendapat nilai minimal 80 . Jika mendapat nilai dibawah 80 , maka peserta didik harus mengulang atau mengikuti remedial.
Untuk tercapainya KKM, guru melakukan berbagai upaya untuk meningkatkan hasil belajar peserta didik seperti pemberian tugas rumah, tugas kelompok dan diskusi. Salah satu upaya yang digunakan untuk meningkatkan hasil belajar peserta didik dengan menerapkan model pelajaran. Model pembelajaran diharapkan dapat merubah suasana kegiatan belajar mengajar menjadi lebih menarik dan membuat peserta didik menjadi lebih antusias dan aktif dalam belajar.

Model pembelajaran yang dapat diterapkan adalah dengan menggunakan model pembelajatan kooperatif.Model pembelajaran kooperatif ini menekankan pada pembelajaran kelompok peserta didik, sehingga membuat peserta didik lebih banyak berinteraksi dengan teman dan guru serta terlibat aktif dalam kegiatan belajar mengajar. Model pembelajaran kooperatif diantaranya adalah Teams Games Tournament dan Numbered Heads Together. Pemilihan kedua model pembelajaran tersebut dikarenakan model pembelajran tersebut mengharuskan peserta didik belajar secara kelompok sehingga membuat peserta didik lebih aktif dan lebih berinteraksi dengan temantemannya.Selain itu, dengan belajar kelompok peserta didik dapat bertukar pikiran dalam menyelesaikan permasalahan pada soal yang diberikan guru.Peserta didik juga bertanggung jawab untuk memahami materi yang disampaikan guru.

Berdasarkan uraian latar belakang tersebut, peneliti tertarik untuk melakukan penelitian mengenai adanya pengaruh hasil belajar antara model pembelajaran kooperatif tipe Teams Games Tournament (TGT) dengan Numbered Heads Together (NHT) pada mata pelajaran Teknik Listrik.

\section{METODOLOGI PENELITIAN}

Populasi dalam penelelitian ini adalah seluruh peserta didik di jurusan Teknik Audio Video. Sampel dalam penelitian ini adalah peserta didik SMK Negeri 39 Jakarta kelas X Teknik Audio Video

Metode yang digunakan dalam penelitian ini adalah metode eksperimen. Metode ekserimen merupakan metode penelitian yang dapat menguji dengan benar hipotesis menyangkut hubungan sebab akibat.(Emzir;2008). Peneliti menggunakan metode eksperimen untuk mengetahui apakah terdapat pengaruh peserta didik yang diajarkan dengan menggunakan model pembelajaran TGT dan model pembelajaran NHT terhadap hasil belajar peserta didik. 
Rancangan penelitian dalam penelitian ini dapat dilihat dari tabel berikut ini :

Tabel 1 Rancangan Penelitian

\begin{tabular}{cccc}
\hline Kelas & Pretest & Perlakuan & Postest \\
\hline $\begin{array}{c}\text { X TAV 1 } \\
\text { (Kelompok } \\
\text { eksperimen) }\end{array}$ & $\mathrm{O}_{1}$ & $\mathrm{X}$ & $\mathrm{O}_{2}$ \\
\hline $\begin{array}{c}\text { X TAV 2 } \\
\text { (Kelompok } \\
\text { Kontrol) }\end{array}$ & $\mathrm{O}_{1}$ & $\mathrm{X}$ & $\mathrm{O}_{2}$ \\
\hline
\end{tabular}

Keterangan :

$\mathrm{X}$ TAV 1 = Peserta didik yang diajar menggunakan model pembelajaran Teams Games Tournament sebagai kelompok eksperimen

X TAV 2 = Peserta didik yang diajar menggunakan model pembelajaran Numbered Heads Together sebagai kelompok kontrol

$\mathrm{O}_{1}=$ Pretest

$\mathrm{O}_{2}=$ Postest

\section{A. Instrumen Penelitian}

Instrumen yang digunakan dalam penelitian ini berupa tes. Tes tersebut berupa soal pilihan ganda. Tes dilakukan sebelum dan sesudah peserta didik diberikan pembelajaran meggunakan model pembelajaran. Tes yang dilakukan bertujuan untuk mengetahui sejauh mana pemahaman peserta didik terhadap materi yang disampaikan oleh guru yang dilakukan pada kedua kelas tersebut. Tes dilakukan menggunakan bentuk soal pilihan ganda (multiple choice) dengan 5 opsi (A, B, C, D dan E).

Sebelum instrumen di uji coba, maka terlebih dahulu instrumen dilakukan validasi. Sebuah instrumen dikatakan valid apabila mampu mengukur apa yang diinginkan. Pada penelitian ini validitas yang digunakan adalah validitas isi dilakukan dengan meminta pertimbangan dari para ahli. Dalam penelitian ini validitas dilakukan oleh guru mata pelajaran teknik listrik jurusan Teknik Audio Video di SMKN 39 Jakarta.

Realibilitas instrumen cukup dapat dipercaya untuk digunakan sebagai alat pengumpul data apabila instrumen tersebut sudah baik. Untuk mengukur tingkat reliabilitas soal menggunakan rumus KR.20. Berdasarkan hasil uji realibilitas yang dilakukan di SMKN 4 Jakarta diperoleh hasil sebesar 0.88 dengan interpretasi tinggi.
Data yang diperoleh hasil penelitian disekolah dideskripsikan untuk memperoleh gambaran tentang pengaruh model pembelajaran terhadap hasil belajar mata pelajaran teknik listrik kelas $\mathrm{X}$ jurusan Teknik Audio Video. Perhitungan terdiri dari mean, median, modus, rentang nilai (interval), standar deviasi, dan variansi yang disajikan dalam bentuk tabel berikut ini :

Tabel 2. Rekapitulasi Data Hasil Belajar Teknik Listrik Model Pembelajaran

\begin{tabular}{ccc}
\cline { 2 - 3 } Statistik & Teams & Numbered \\
& Games & Heads \\
& Tournament & Together \\
& (Kelompok & (Kelompok \\
& Eksperimen) & Kontrol)
\end{tabular}

\begin{tabular}{lcc}
\hline $\begin{array}{l}\text { Nilai } \\
\text { Tertinggi }\end{array}$ & 86 & 90 \\
\hline $\begin{array}{l}\text { Nilai } \\
\text { Terendah }\end{array}$ & 56 & 53 \\
\hline Mean & 76,62 & 70,72 \\
\hline Median & 78,9 & 71,96 \\
\hline Modus & 81,75 & 78,75 \\
\hline $\begin{array}{l}\text { Rentang } \\
\text { Nilai }\end{array}$ & 30 & 37 \\
\hline $\begin{array}{l}\text { Standar } \\
\text { Deviasi }(S)\end{array}$ & 7,78 & 9,96 \\
\hline $\begin{array}{l}\text { Variansi(S } \\
\text { (S) }\end{array}$ & 60,53 & 99,21 \\
\hline
\end{tabular}

Pada penelitian ini, peneliti menganalisis data pengukuran awal (pretest) dan pengukuran akhir (posttest) peserta didik kelompok eksperimen untuk melihat apakah terdapat perbedaan mengenai hasil belajar peserta didik kelas X TAV 1 antara pretest dan posttest setelah diberikan perlakuan menggunakan model pembelajaran kooperatif tipe TGT.

Tabel 3. Distribusi frekuensi hasil pretest kelompok eksperimen

\section{HASIL DAN PEMBAHASAN}




\begin{tabular}{ccccccc}
\hline Kelas & Nilai & $\mathrm{f}$ & $\mathrm{fk}$ & $\begin{array}{c}\text { Batas } \\
\text { Bawah }\end{array}$ & $\begin{array}{c}\text { Batas } \\
\text { Atas }\end{array}$ & $\mathrm{X}$ \\
\hline 1 & $13-16$ & 5 & 5 & 12.5 & 16.5 & 14.5 \\
\hline 2 & $17-20$ & 5 & 10 & 16.5 & 20.5 & 18.5 \\
\hline 3 & $21-24$ & 7 & 17 & 20.5 & 24.5 & 22.5 \\
\hline 4 & $25-28$ & 3 & 20 & 24.5 & 28.5 & 26.5 \\
\hline 5 & $29-32$ & 4 & 24 & 28.5 & 32.5 & 30.5 \\
\hline 6 & $33-36$ & 5 & 29 & 32.5 & 36.5 & 34.5 \\
\hline Jumlah & & 29 & & & & \\
\hline
\end{tabular}

Gambar1. Diagram frekuensi nilai pretest pada kelompok eksperimen

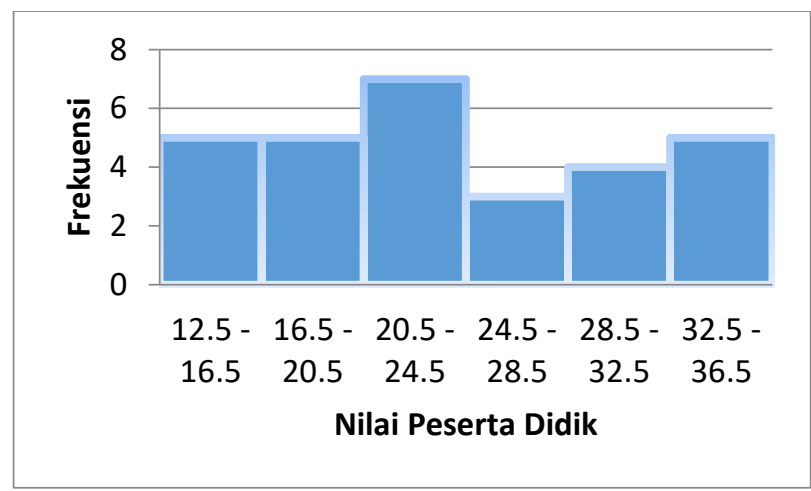

Tabel 4. Distribusi frekuensi hasil posttest kelompok eksperimen

\begin{tabular}{ccccccc}
\hline Kelas & Nilai & fi & fk & $\begin{array}{c}\text { Batas } \\
\text { Bawah }\end{array}$ & $\begin{array}{c}\text { Batas } \\
\text { Atas }\end{array}$ & X \\
\hline 1 & $56-60$ & 2 & 2 & 55.5 & 60.5 & 58 \\
\hline 2 & $61-65$ & 2 & 4 & 60.5 & 65.5 & 63 \\
\hline 3 & $66-70$ & 1 & 5 & 65.5 & 70.5 & 68 \\
\hline 4 & $71-75$ & 4 & 9 & 70.5 & 75.5 & 73 \\
\hline 5 & $76-80$ & 8 & 17 & 75.5 & 80.5 & 78 \\
\hline 6 & $81-85$ & 12 & 29 & 80.5 & 85.5 & 83 \\
\hline Jumlah & & 29 & & & & \\
\hline
\end{tabular}

Tabel 6. Distribusi frekuensi hasil posttest kelompok kontrol

\begin{tabular}{ccccccc}
\hline Kelas & Nilai & f & fk & $\begin{array}{c}\text { Batas } \\
\text { Bawah }\end{array}$ & $\begin{array}{c}\text { Batas } \\
\text { Atas }\end{array}$ & X \\
\hline 1 & $53-59$ & 6 & 6 & 52.5 & 59.5 & 56 \\
\hline 2 & $60-66$ & 3 & 9 & 59.5 & 66.5 & 63 \\
\hline 3 & $67-73$ & 7 & 16 & 66.5 & 73.5 & 70 \\
\hline 4 & $74-80$ & 9 & 25 & 73.5 & 80.5 & 77 \\
\hline 5 & $81-87$ & 3 & 28 & 80.5 & 87.5 & 84 \\
\hline 6 & $88-94$ & 1 & 29 & 87.5 & 94.5 & 91 \\
\hline Jumlah & 29 & & & & \\
\hline
\end{tabular}

Pada kelompok kontrol juga diberlakukan hal yang sama, peneliti menganalis data pengukuran awal (pretest) dan pengukuran akhir (posttest) peserta didik kelompok kontrol untuk melihat apakah terdapat perbedaan mengenai hasil belajar peserta didik kelas X TAV 2 antara pretest dan posttest setelah diberikan perlakuan menggunakan model pembelajaran kooperatif tipe NHT.

Tabel. 5 Distribusi frekuensi hasil pretest kelompok kontrol

\begin{tabular}{ccccccc}
\hline Kelas & Nilai & fi & fk & $\begin{array}{c}\text { Batas } \\
\text { Bawah }\end{array}$ & $\begin{array}{c}\text { Batas } \\
\text { Atas }\end{array}$ & X \\
\hline 1 & $16-20$ & 6 & 6 & 15.5 & 20.5 & 18 \\
\hline 2 & $21-25$ & 5 & 11 & 20.5 & 25.5 & 23 \\
\hline 3 & $26-30$ & 7 & 18 & 25.5 & 30.5 & 28 \\
\hline 4 & $31-35$ & 4 & 22 & 30.5 & 35.5 & 33 \\
\hline 5 & $36-40$ & 5 & 27 & 35.5 & 40.5 & 38 \\
\hline
\end{tabular}

Gambar 3. Diagram frekuensi nilai posttest pada kelompok kontrol

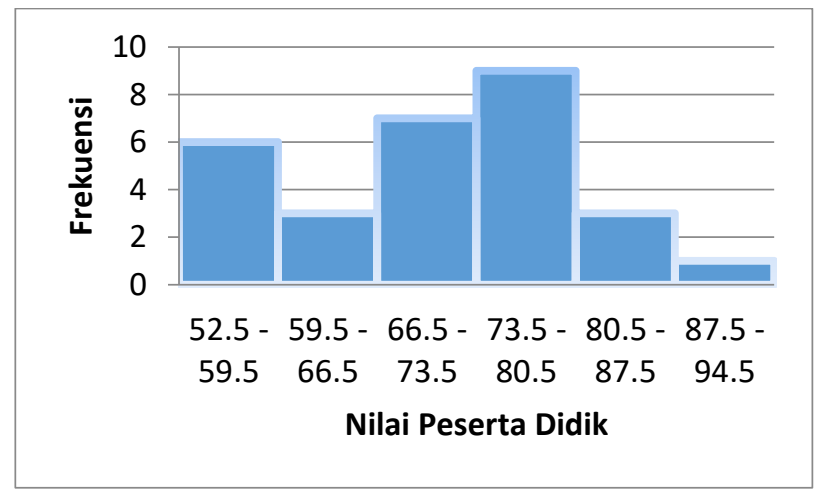


Uji Normalitas dilakukan untuk menilai sebaran data pada sebuah kelompok berasal dari populasi berdistribusi normal atau tidak. Pada penelitian ini untuk menghitung uji normalitas menggunakan uji Liliefors.

Tabel. 6. Hasil Uji Normalitas

\begin{tabular}{cccccc}
\hline Kelompok & $\mathrm{N}$ & $\alpha$ & $\begin{array}{c}\mathrm{L} \\
\text { hitung }\end{array}$ & $\begin{array}{c}\mathrm{L} \\
\text { tabel }\end{array}$ & Keterangan \\
\hline Eksperimen & 29 & 0,05 & 0,154 & 0,161 & Normal \\
\hline Kontrol & 29 & 0,05 & 0,116 & 0,161 & Normal
\end{tabular}

Pada kelompok eksperimen dengan menggunakan taraf signifikan 0,05 dengan sampel sebanyak 29 orang diperoleh $\mathrm{L}_{\text {tabel }}$ sebesar 1,161 . Setelah dilakukan perhitungan dengan uji Liliefors diperoleh $\mathrm{L}_{\text {hitung }}$ sebesar 0,154 . Karena $\mathrm{L}_{\text {hitung }}$ kurang dari $\mathrm{L}_{\text {tabel }}(0,154<1,161)$, maka dapat disimpulkan bahwa pada kelompok eksperimen data berasal dari populasi distribusi normal. Sedangkan pada kelompok kontrol, dengan taraf signifikan 0,05 dan sampel sebanyak 29 orang diperoleh $\mathrm{L}_{\text {tabel }}$ sebesar 1,161. Setelah dilakukan perhitungan diperoleh $\mathrm{L}_{\text {hitung }}$ sebesar 0,116 . Karena $\mathrm{L}_{\text {hitung }}$ kurang dari $\mathrm{L}_{\text {tabel }}$ $(0,116<1,61)$, maka dapat disimpulkan bahwa pada kelompok kontrol data berasal dari populasi distribusi normal.

Dalam penelitian ini, uji homogenitas dilakukan menggunakan uji Fisher. Dari hasil perhitungan diperoleh nilai varians pada kelompok eksperimen sebesar 75,95 dan pada kelompok kontrol 132,97. Sehingga diperoleh $F_{\text {hitung }}$ sebesar I,75 dengan taraf signifikan 0,05 diperoleh $\mathrm{F}_{\text {tabel }}$ sebesar 1,87. Berdasarkan hasil perhitungan, $F_{\text {hitung }}$ kurang dari $F_{\text {tabel }}(1,75<1,87)$ maka dapat disimpulkan bahwa varians kedua populasi homogen.

Setelah melakukan uji prasyarat dan diketahui bahwa kedua kelompok berdistribusi normal dan homogen, maka tahap pengujian selanjutnya adalah pengujian hipotesis dengan uji t. Berdasarkan hasil pengujian nilai rata-rata posttest mata pelajaran teknik listrik dengan menggunkan uji $t$, diperoleh nilai thitung $=2,12$ dan diperoleh nilai $t_{\text {tabel }}=2,00$. Hasil perhitungan menunjukkan bahwa nilai $t_{\text {hitung }}>$ lebih besar $t_{\text {tabel }}(2,12>2,00)$ maka $\mathrm{H}_{0}$ ditolak dan $\mathrm{H}_{1}$ diterima, sehingga dapat disimpulkan bahwa terdapat pengaruh hasil belajar antara peserta didik yang menggunakan model pembelajaran Teams Games Tournament dan peserta didik yang menggunakan model pembelajaran Numbered Heads Together.

\section{KESIMPULAN}

Berdasarkan hasil analisis data pada pembahasan yang telah dijelaskan, maka dapat ditarik kesimpulan bahwa pada hasil penelitian yang dilakukan di SMKN 39 Jakarta pada kelas X jurusan TAV 1 dan TAV 2 menunjukkan terdapat perbedaan hasil belajar pesera didik dengan menerapkan model pembelajaran kooperatif Teams Games Tournamen (TGT) dan model pembelajaran kooperatif tipe Numbered Heads Together (NHT) .

\section{DAFTAR PUSTAKA}

[1] Arikunto, Suharsimi. (2011). Dasar-Dasar Evaluasi Pendidikan. Jakarta: PT. Bumi Aksara.

[2] Arikunto, Suharsimi. (2006). Prosedur Penelitian Suatu Pendidikan Praktik. Jakarta: Rineka Cipta.

[3] Devioga, Fransiska. (2014). Efektivitas Metode Pembelajaran Kooperatif Tipe TGT Terhadap Peningkatan Keaktifan Dan Prestasi Belajar Kelas X Mata Pelajaran Teknik Listrik Di SMK N 2 Yogyakarta [skripsi]. Yogyakarta: Fakultas Teknik, Universitas Negeri Yogyakarta.

[4] Dimyati. (2006). Belajar dan Pembelajaran. Jakarta: Rineka Cipta.

[5] Djamarah, Syaiful Bahri \& Aswan, Zain. (2010). Strategi Belajar Mengajar. Jakarta: Rineka Cipta.

[6] Fakultas Teknik. (2015). Buku Panduan Penyusunan Skripsi Dan Non Skripsi. Jakarta: Fakultas Teknik, Universitas Negeri Jakarta.

[7] Emzir,. (2008). Metodologi Penelitian Pendidikan Kuantitatif dan Kualitatif. Jakarta: PT Rajagrafindo Persada. 
[8] Hamalik, O. (2009). Proses Belajar MengajJakarta: PT Bumi Aksara.

[9] Isjoni,. (2013). Cooperatife Learning (Efektivitas Pembelajaran Kelompok). Bandung: Alfabeta.

[10] Jihad, Asep \& Abdul Haris,. (2012). Evaluasi Pembelajaran. Yogyakarta: Pressindo.

[11] Komalasari, Kokom,. (2010). Pembelajaran Konseptual Konsep dan Aplikasi. Bandung: PR Rifeka Aditama.

[12] Nas, Moch. Khoirun \& Edy Sulistyo,. (2013). Pengaruh MOdel Pembelajaran Kooperatif Tipe Learning Togeher Terhadap Hasil Belajar Siswa Pada Mata Pelajaran Diklat Menjelaskan Dasar-Dasar Sinyal Video Di SMK Negeri 1 Sidoarjo. Jurnal Pendidikan Teknik Elektro , 941.

[13] Pratiwi, Sari Eka. (2015). Pengaruh Kombinasi Model Pembelajaran Kooperatif Tipe Numbered Heads Together (NHT)-Teams Games Tournament (TGT) Terhadap Motivasi dan Hasil Belajar Biologi Siswa Kelas XI SMA Negeri 1 Sewon. [Skripsi]. http://digilib.unimed.ac.id/8352/

Diakses 26 Januari 2017

[14] Purwanto, Erwan Agus \& Dyah Ratih Sulistyastuti,. (2007). Metode Penelitian Kuantitatif Untuk Administrasi Publik dan Masalah-Masalah Sosial. Yogyakarta: Gava Medika.

[5] Purwanto,. (2010). Evaluasi Hasil Belajar. Yogyakarta: Pustaka Pelajar.

[16] Rusman,. (2012). Model-Model Pembelajaran : Mengembangkan Profesionalisme Guru. Jakarta: RaJa Grafindo Persada.
[17] Sanjaya, Wina,. (2006). Pembelajaran dalam Implementasi Kurikulum Berbasis Kompetensi. Jakarta: Kencana.

[19] Shoimin, Aris,. (2014). 68 Model Pembelajran Inovatif Dalam Kurikulum 2013. Yogyakarta: Ar-ruzz Media.

[20] Slameto,. (2003). Belajar dan FaktorFaktor yang Mempengaruhinya. Jakarta: Rineka Cipta. 